\title{
胸郭出口症候群における腕神経叢の障害
}

\author{
信州大学医学部整形外科学教室 \\ 前田道宣・山岡弘明 \\ 大 塚 訓 喜
}

\section{Compression of the Brachial Plexus caused by the First Rib in the Thoracic Outlet Syndrome}

\author{
By \\ M. Maeda, H. Yamaoka and K. Ohtsuka \\ Department of Orthopaedic Surgery, Faculty of Medicine, \\ Shinshu University, Matsumoto, Japan
}

The features of thoracic outlet syndrome as follows are very important:

1) Symptoms appeared even in a posture that had not influence on radial pulse.

2) The frequency of brachial plexus tenderness associated with radiating pain was extremely high in the affected side.

3) Sensory disturbance was noticed chiefly along the ulnar side of the arm.

4) Many patients complained of various symptoms in addition to those of upper extremity.

5) Compression lesions of the brachial plexus were found by surgical exploration.

From the above, we consider that thoracic outlet syndrome may be one kind of entrapment neuropathies of the brachial plexus.

\section{緒 言}

胸郭出口症候群という呼称は, 1956 年 Peet ら6) により，それまで前斜角筋症候群，肋鎖症候群，過外 転症候群などとよばれていたものを総称する症候群と して提唱されたものである．本疾患がひきおてされる 直接の原因となる構築物や部位については様々な推測 がなされている，しかしその発症機転については不明 な点が多く，論議のあるところである.われわれは治 験例について, 理学的所見, 臨床症状, 光電指尖容皘 脈波，鎖骨下動脈造影像，発症様式，手術所見につい て検討しその主因を追求した。

\section{症例}

昭和 48 年から昭和 52 年までの 5 年間に当科で胸郭 出口症候群之診断されたものは, 男 19 名, 女 89 名, 計 108 名で，初診時平均年令はそれぞれ 30.7 才, 28.6 才である. 年令分布をみると, 10 才代 12 例
(11.1\%)，20才代 58 例 (53.7\%)，30才代 19 例 (17.6\%)，40才代 16 例 (14.8\%)，50才代 3 例（2.8 \%) で，10才代と 20 才代で全体の約 3 分の 2 を占め る. このうち症状の重いあの 35 例 43 肢に光電指尖容 積脈波を，17 例に 鎖骨下動脈造影を施行した，保存 的治療が無効で手術を行なったのは 12 例 15 肢であ る.

I. 神経血管束圧迫テストにおける脈拍の途絶と症 状発現との関係

光電指尖容積脈波を施行した 35 例 43 肢について検 討する. Wright, Eden の各テストのいずれかで脈 拍の途絶したものは患肢 43 肢中 29 肢 (67\%) で, そ のうちわけは Wright のテストが 27 肢, Eden のテ ストが 10 肢である，一方健肢についてみると，27 肢 中 14 肢 $(52 \%)$, Wright のテストで 13 肢, Eden のテストで 4 肢にやはり脤拍の途絶をみている．患肢 では全肢ともこれらのテスト施行時に症状の発現ない し増強があったが，健肢では脈拍の途絶した 14 肢中 
4 肢のみであった. すなわち, 脈拍の途絶と症状の発 現には必ずしも関連性は認められなかったが，患肢は あちろんのとと健肢にあ症状をひき扣とすこれらのテ ス卜は，汃なり過酷な肢位と考えられる。

\section{II. 腕神経叢における圧痛，上肢への放散痛}

全症例についてみると, 患肢では 129 肢中 95 肢 (73.6\%) にみられたが，健肢では 73 肢中 3 肢（4.1 \%)のみであった，脈波を旋行した症状の重い症例で は，患肢 43 肢中 35 肢（81.4\%），健肢 27 肢中 3 肢 (11.1\%) と，いずれも比率はやや高くなるが，明ら かに患肢において高率にみられた。

\section{III. 知覚障害}

全症例 108 例 129 肢中 47 肢 (36.4\%), 症状の重か った 43 肢中では 24 肢（55.8\%） 飞知覚障害を認め た. 知覚障害の範囲は様々であるが, 多くは前腕から 手にかけての尺側に高度な障害がみられた．乙れは後 述もするが，腕神経叢の第 1 肋骨に接する下神経幹が 主に障害されるためと考えられる.

\section{IV. 臨床症状}

本症患における症状はバラエティーに富むが，主な 症状およびその発生率は表 1 に示すごとくである. 側 頸部〜手の疼痛, 前腕〜手のしびれ, 項部〜背部痛, 肩てり，腕のだるさなどが数多くみられる症状である が，障害の拈きている胸郭出口周辺の症状はもちろん のこと, 部位的・解剖学的に障害部位とはかなりかけ 離れた部位にも症状を有するととに気がつく，とのよ うな症状がおこる理由については後述する.

\section{V. 鎖骨下動脈造影像}

われわれは保存的治療が無効でかつ愁訴のつよいむ のに対し，手術を前提として鎖骨下動脈造影を行なっ ている. これまで 17 例に対して施行した. その結果 Wright のテストの肢位では患肢 21 肢中 14 肢に㻖窄 を，5肢に閉塞をみているが， 2 肢は正常であった. 一方健肢についてみると, 13 肢中 5 肢に狭窄, 3 肢 に閉塞像を呈しており，乙の肢位で鎖骨下動脈に異常 を認めないものは 4肢のみであった。

\section{VI. 手術について}

当科に执ける手術例は 12 例 15 肢である. いずれす $\operatorname{Roos}^{7)}$ の transaxillary approach にて前・中斜角 筋切離, 第 1 肋骨切除術を施行した. この 12 例につ いて肢位之症状の発現, その時の橈骨動脈の拍動の変 化との関連をみた。 まず下垂位の状態では，脈拍はす べて正常であったが，3肢においてはすでに腕のだる
表 1 . 塸床症状とその発生頻度

\begin{tabular}{|c|c|c|}
\hline $\begin{array}{l}1 . \\
2 . \\
3 . \\
4 . \\
5 . \\
6 . \\
7 . \\
7 .\end{array}$ & 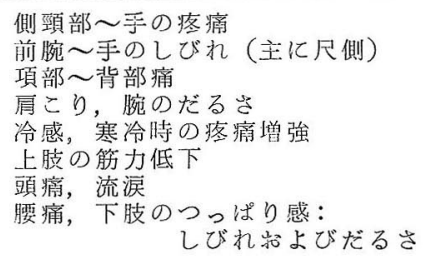 & $\begin{array}{l}44 \% \\
61 \% \\
50 \% \\
72 \% \\
25 \% \\
17 \% \\
17 \% \\
25 \%\end{array}$ \\
\hline
\end{tabular}

さやしびれを訴えていた．50〜60挙上位，乙れはほ ぼ机に肘をおいた肢位であるが，乙れでは脈拍には変 化をみないにもかかわらず全例に症状の発現をみた。 非手術例でもこのような肢位, 具体的には車の運転, はみがき, レジを打つこと, 事務の仕事などで症状を 訴えるものがかなりみられた. Wright のテストでは 1 例を除き, 脈拍の減弱・消失之, 症状の発現・増悪 をみた，代表的な症例をあげる.

症例. 45 才, 女性. 主訴は右肩甲帶から右手にか けての疼痛と, 右前腕から手にかけての尺側のしびれ がある. 図 1 のような肢位で発症する。乙の肢位では 脈波には何ら変化を認めず, Wright のテストでは

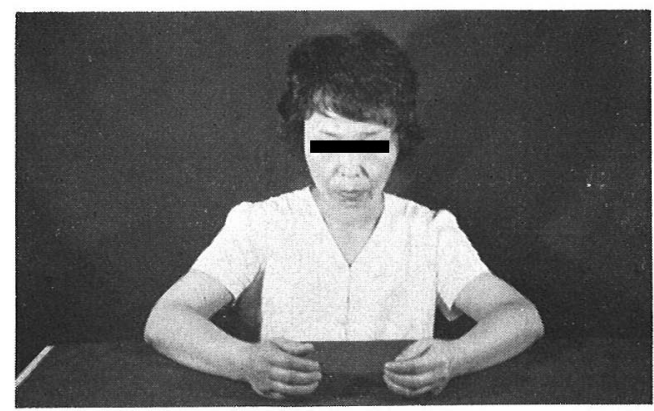

図1患者は机に时を置いただけで発症する。

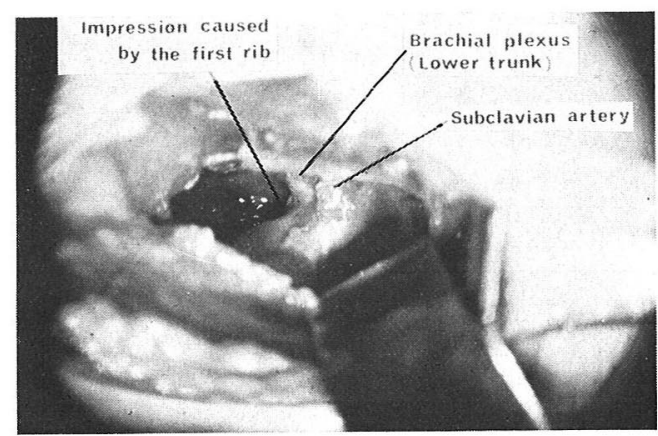

図2 右第 1 肋骨を切除した後の写真である。 下神経翰に著明な圧痕を認好。 
鎖骨下動脈造影像，脈波共にむしろ健側の方に高度の 狭窄像之脈拍の途絶を認めた. 手術所見では図 2 ので とく腕神経叢に著明な圧痕を認めた. われわれは最近, 腕神経叢の障害の有無に注意して手術を行なうように してからの 7 肢すべてに, 神経に 圧痕を 確認してい る.

\section{VII. 術後の脈波}

術後直接検診しえた症例は 12 例中 10 例であるが, このうち 3 例に脈拍の途絶をみている. 術後の銷骨下 動脈造影は施行していないので圧迫部位は不明である が， 1 例は何ら愁訴はなく，他の 2 例も Wright の テストの肢位をとった時手にしびれを訴えていたが, ADL には支障なかった.

\section{考案}

胸郭出口症候群は多彩な臨床像を呈し, 明確な猃断 をつけることが困難であるばかりでなく，その主因あ 銷骨下動脈閉塞障害によるのか, 腕神経叢の圧迫障害 によるのか不明な点が多い.われわれの調査結果をあ 之にての点についての考察を加えてみたい.

本症が銷骨下動脈の閉塞によって生じるという説は Gilroy ら3)が述べている. その理由として, (1)症状 が肢位によって急激な変化をおてし，レイノ一症状や 血栓症を伴うことがあるとと. (2)皮庯や爪の栄養障害 がおこること. (3)過外転位における 症状の 発現に 際 し, 橈骨動脈の拍動の消失・減弱をみ, 聴診上鎖骨上 窩で雥音が聴取され，末梢側にて 血圧が 低下するて 之. (4)同肢位での血管造影で狭窄像がみられるとと. (5)知覚障害の分布領域にはむらがあり, 神経の支配領 域と一致していないてと.などの点をあげている（表 2).乙れまでの報告例をみてあ(1) (2)は血管症状とし て説明されているあのが多い. しかしてれらはむしろ 神経障害によるものとわれわれは推測している. その 詳細については後に述べることにして, 本症では過外 転位をとらずとも発症するのはよくみられることで,

\section{表 2. 鎖骨下動脈障害説（Gilroy ら）}

\footnotetext{
(1) 症状が肢位によって急激に変化し，レイノ 一症状や血栓症を伴うことがある。

(2) 皮唐や爪の栄養障害.

(3)過外転位に拈ける橈骨動脈拍動の消失・減 弱, 鎖骨上窝での雑音の聴取, 末梢側に括 ける血圧低下。

(4) 過外転位に拈ける血管造影での狭窄像。
}

(5)神経の支配領域に一致しない知覚障害.
患側が日常生活の中でこのような過外転位をとること はむしろ稀である．乙の肢位は一種の誘発試験であ り, 銷骨下動脈のみならず, 腕神経叢も圧迫されるこ とは十分考えられる. われわれの調査結果では次のよ うなととが明らかとなっている.すなおち

1) 鎖骨下動脈造影や指尖容積脈波にて完全通過障 害があっても無症状のあのがある.

2) 脈拍に直接影響をおよぼさない肢位でも発症す る.

3 ）上肢以外飞も症状の拡大がみられる.

てのような事実からして, Wright のテスト，

Eden のテストなどで発症し，鎖骨下動脈の障害をみ るからといって, 銷骨下動脈の閉塞障害を本疾患の主 因とするには多くの矛盾と疑問がある. Wright のテ スト, Eden のテストなどで脈拍が減弱, 消失するの は肋鎖間隙等の狭さを示すすのとしては価值がある が，このとと自体は病的なあのではないとわれわれは 考えている. Wright ${ }^{13)}$ 屯正常人 150 人について過外 転テストを行ない，右肢 $83.3 \%$, 左肢 $82 \%$ に脈拍の 途絶をみたと報告している. (5)の知覚障害の領域に関 しては，われわれの経験例では前腕から手にかけての 尺側領域に高度な知覚障害がみられた. 腕神経叢が肋 鎖間において障害をうける場合，われわれの手術所見 （前述）で明らかにされたように，第 1 肋骨によって 障害されるものが多い. 腕神経叢の下神経幹はこの第 1 助骨に最も隣接しているので, 知覚障害が尺側に起 こる頻度が大きいのは当然のことであろうと考える.

次に, 従来血管症状之されていた冷感, 寒冷時の症 状增悪, 皮膚の蒼白化など（表 2 1)）はどのように解 釈すべきだろうか. Blair ${ }^{1)}$, McGowan ${ }^{4)}$, Telford 10111)，Williams ${ }^{12)}$ らは，下神経幹には多くの交感神 経が含まれており，乙れが直接圧迫されることによ り, あるいは反復される圧迫, 牽引によって neuritisをおこして刺激され arterial spasmをおこすと 述べている. てれがさらに持続すれば vasa vasorum が閉塞し, 動脈壁の栄養障害をきたして血栓を 形成するとしている．広義ではてれらの症状は血管症 状であろうが, これは腕神経叢の障害から 2 次的に惹 起されたあのと考える.

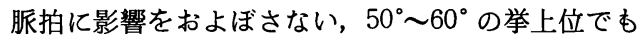
発症するという現象はいかに解釈すべきだろうか．小 野ら ${ }^{5)}$ は屍体において, 第 7 頸椎間孔一斜角筋三角一 銷骨下一鳥口突起下一肩関節下－肘関節までの距離 
を上肢の 肢位，頭位と関係づけて調査している．そ れによると上肢下垂位ではこの全経路は $38 \mathrm{~cm}, 90^{\circ}$ 外転位で $40 \mathrm{~cm}$, 最大外転位で $37 \mathrm{~cm}$ となる. この 変化は, 上肢の運動中心が肩関節にあり神経の走行は 骨格とはずれているために生じるものである．上肢を 挙上していくと神経走行距離は増大し, 神経に加わる 張力む大きくなる．乙れは弓と弦との関係を想像すれ ば理解しやすい，健康人ではこの程度の神経走行経路 の変化は問題とならないが，本症をおこしている患者 では肩甲帯下降による神経走行の余裕の減少，反復刺 激による神経の過敏性などの要素が，わずかの腕の動 きであ神経に障害をひきおこすことになるすのと思わ れる. 前述したごとく，患側の腕神経叢に高率に圧 痛，上肢への放散痛を認めたととは，同部に何らかの 病的変化が生じていることを示唆するものと考える.

曽我 ${ }^{879)}$ は鎖骨下動脈造影を中心にした研究で， 斜角筋部，肋銷間，小胸筋・胸壁間などでの血管の狭 窄・途絶を証明しているが，乙の時血管に対する影響 と共に，随走する神経にあ障害がおよぶであろうと想 像することは可能である。

最後に上肢以外の部位にみられる症状について述へ る. 臨床症状の項で述べたような頭痛, 流涙, 下肢の つっぱり感・しびれ，腹痛のほかに，耳鳴り，眼の充 血，めまいなどを訴えるものもある．注目すべきこと は, これらの症状は患側の半身のみに限られていたて とである．当初これらは別の疾患によるあのと考えて いたが，乙のような症例に頸部硬膜外麻酔や星状神経 節ブロック，さらには局所の圧痛点をブロックするこ とにより一過性ではあるがこの種の症状の消失，軽快 がおこることから，現在は胸郭出口症候群に伴う一連 の症状と考えている.

この点について Bonica ${ }^{2)}$ は reflex sympathetic dystrophies という概念で説明している. これは外傷 などを契機として持続的な刺激が末梢の知覚神経に加 えられると，反射的な交感神経の異常状態を，障害部 を中心に脊髄を介して広範にひきおこし，血行および 栄養障害をきたす症候群であるという，原因としては 外傷性, 症候性, 特発性をあげているが, 胸郭出口症 候群あ原因の一つとして述べている．そのメカニズム については, 障害部位からの afferent impulse が 脊髄に達し, internuncial pool の障害を起こし, そ の分節の骨格筋および平滑筋を支配する anterior お よび lateral horn cell の活動性が増加して必要以上
の motor impulse をその支配域の血管や汗腺，筋肉 などに送り，その結果障害部位は血行障害や筋攀縮を きたし，代謝異常を惹起しててれがますます大きな刺 激を脊髄に送ることになり，悪循環が成立すると説明 している．乙の交感神経性の障害は初期のうちは障害 部位だけの分節に限局されているが，しだいに上下の 分節にまでおよび，ついには反対側にまでおよぶとい う. 臨床症状としては, 直接的に障害されている神経 の走行には必ずしも一致しない部位での灼熱的な疼 痛，局所的な hyperestesia，血管運動神経の障害に によるチアノーゼ・冷感・皮㓺蒼白化, 浮腫, 筋萎 縮，筋力低下などをひきおこす．乙れはあくまでも仮 説ではあるが，われわれは本疾患において前出したよ うな症状の拡大を実際に経験しており，現在のところ てのような仮説をあってしなければ説明がつかないと ころである.

\section{ま と め}

1. 当科における過去 5 年間の胸郭出口症候群につ いて検討した

2. 脈拍の途絶と症状の発現とには関連性が認めら れなかった.

3．脈拍に直接影響をおよぼさない肢位でも発症す る.

4. 患肢の腕神経叢では高率に圧痛，上肢への放散 痛が認められた。

5，知覚障害は主として尺側に高度な障害がみられ た.

6.上肢以外へも症状の拡大がみられた

7. 以上の結果, 本疾患の主因を血管障害に求める ことには多くの矛盾があるが，腕神経叢の entrapment による障害と考えればおおかたの問題点は解決 される.われわれの手術例であこれを裏づけるような 所見を，腕神経叢の王痕像として確認している.

\section{文献}

1) Blair, D. M. et al.: The Etiology of the Vascular Symptoms of Cervical Rib, Brit. J. Surg., 22, 406, 1935.

2) Bonica, J. J.: The Management of Pain, 2nd Ed., p. 913, Lea \& Febiger, Philadelphia, 1972.

3) Gilroy, J. et al. : Compression of the Subclavian Artery as a Cause of Ischemic Brachial Neuropathy, Brain, 86, 733, 1963. 
4) McGowan, J. M. et al.: Costoclavicular Compression, Arch. Surg., 59, 62, 1949.

5）小野啓郎ほか：いわゆる thoracic outlet compression syndrome について. 臨整外. 5, 375, 1970.

6) Peet, R. M. et al.: Proc. Staff Meet. Mayo Clic., 281，1956, 曽我 ${ }^{8)}$ より引用.

7) Roos, D. B.: Transaxillary Approach for First Rib Resection to Relieve Thoracic Outlet Syndrome, Ann. Surg, 163, 3, 354, 1966.

8）曽我恭一ほか：Thoracic Outlet Syndrome の臨床像。整形外科. 25, 185, 1974.

9）曽賀恭一ほか：血管撮影所見より見た thoracic outlet syndrome 発症メカニズムについて。臨 整外. 10, 314, 1975 .

10) Telford, E. D. et al.: The Vascular Complications of Cervical Rib, Brit. J. Surg., $18,557,1931$.

11) Telford, E. D. et al.: Pressure at the Cervico-Brachial Junction, J. Bone Joint Surg., 30-B, 249, 1948.

12) Williams, A. F.: The Role of the First Rib in the Scalenus Anterior Syndrome, J. Bone Joint Surg., 34-B, 200, 1952.
13) Wright, C. I. S.: The Neurovascular Syndrome Produced by Hyperabduction of the Arms, Amer. Heart J. al, 29, 1, 1945.

\section{質 問東大 立石 昭夫}

神経症状を強調しているが，私のこれまでの経験で は過半数の症例では脈管症状と神経症状が mix した あののように思う. 特に上肢のだるさ，しびれ，痛み などはその原因として阻血性のものがかなり関与して いるように思う.

\section{回答信州大 前田 道宣}

われわれむ血管性の因子を全く否定しているわけで はない. しかし，臨床症状，その発症様式などを検討 してみると，鎖骨化動脈の閉塞としては説明のつかな い点が多々みられる．下神経幹には交感神経が多く含 まれており，従来血管障害によるといわれていた症状 の中に，交感神経の障害によってひきおこされた angio spasm の結果おこっているものもあると考え る. 